\title{
Biological Function and Application of Picornaviral 2B Protein: A New Target for Antiviral Drug Development
}

\author{
Zengbin Li ${ }^{1}$, Zixiao Zou ${ }^{2}$, Zeju Jiang ${ }^{3}$, Xiaotian Huang ${ }^{2}$ and Qiong Liu ${ }^{2, *(\mathbb{D}}$ \\ 1 School of Public Health, Nanchang University, Nanchang 330006, China; nculizengbin@163.com \\ 2 Department of Medical Microbiology, School of Medicine, Nanchang University, Nanchang 330006, China; \\ zzx1019446427@163.com (Z.Z.); xthuang@ncu.edu.cn (X.H.) \\ 3 Jiangxi Medical College, Nanchang University, Nanchang 330006, China; jiangzeju1998@126.com \\ * Correspondence: p19890528@126.com
}

Received: 13 May 2019; Accepted: 2 June 2019; Published: 4 June 2019

\begin{abstract}
Picornaviruses are associated with acute and chronic diseases. The clinical manifestations of infections are often mild, but infections may also lead to respiratory symptoms, gastroenteritis, myocarditis, meningitis, hepatitis, and poliomyelitis, with serious impacts on human health and economic losses in animal husbandry. Thus far, research on picornaviruses has mainly focused on structural proteins such as VP1, whereas the non-structural protein $2 \mathrm{~B}$, which plays vital roles in the life cycle of the viruses and exhibits a viroporin or viroporin-like activity, has been overlooked. Viroporins are viral proteins containing at least one amphipathic $\alpha$-helical structure, which oligomerizes to form transmembrane hydrophilic pores. In this review, we mainly summarize recent research data on the viroporin or viroporin-like activity of $2 \mathrm{~B}$ proteins, which affects the biological function of the membrane, regulates cell death, and affects the host immune response. Considering these mechanisms, the potential application of the $2 \mathrm{~B}$ protein as a candidate target for antiviral drug development is discussed, along with research challenges and prospects toward realizing a novel treatment strategy for picornavirus infections.
\end{abstract}

Keywords: picornavirus; 2B protein; viroporin; drug development

\section{Introduction}

The Picornaviridae family consists of 35 genera and 80 species, mainly including Enterovirus, Hepatovirus, Cardiovirus, Aphthovirus, and Rhinovirus [1]. To date, research on picornaviruses has mainly focused on enterovirus (EV) 71, coxsackievirus (CV), poliovirus (PV), encephalomyocarditis virus (EMCV), foot-and-mouth disease virus (FMDV), human rhinovirus (HRV), and hepatitis A virus (HAV). Picornavirus infections can cause enormous damage in humans and animals. The EV71, CVA16, and CVA10 cause hand, foot, and mouth disease in millions of children in Asia-Pacific region each year and can cause more serious clinical symptoms such as aseptic meningitis, acute flaccid paralysis, and neurological respiratory syndrome [1-3].

Picornaviruses are non-enveloped spherical viruses with an icosahedral-structured viral capsid. The picornaviral genome consists of a single-stranded positive-sense RNA, which is approximately 6.7-10.1 kilobases in length, with a highly conserved structure, including a $5^{\prime}$-noncoding region (5'-NCR), an open reading frame, a $3^{\prime}-\mathrm{NCR}$, and a $3^{\prime}$-end polyA tail [1]. The $5^{\prime}$-NCR contains multiple RNA secondary structural elements, including the internal ribosome entry site. The open reading frame of the viral genome consists of three regions: P1, P2, and P3. The P1 region is translated and processed to form the structural proteins VP1, VP2, VP3, and VP4, which compose the capsid structure 
of a picornavirus. The $\mathrm{P} 2$ and $\mathrm{P} 3$ regions are separately translated to the non-structural proteins $2 \mathrm{~A}, 2 \mathrm{~B}$, and $2 \mathrm{C}$ and $3 \mathrm{~A}, 3 \mathrm{~B}, 3 \mathrm{C}$, and $3 \mathrm{D}$, respectively. The majority of related research has focused on structural proteins of picornaviruses, such as VP1, whereas the importance of the non-structural protein $2 \mathrm{~B}$ has been relatively overlooked.

Viroporins are proteins found in a variety of viruses and are generally comprised of 50 to 120 amino acids. Each viroporin contains a highly hydrophobic domain capable of forming at least one amphipathic $\alpha$-helical structure, which oligomerizes to form transmembrane hydrophilic pores $[4,5]$. The 2B protein is a crucial component of picornaviruses that exhibits viroporin or viroporin-like activity, plays a key role in the picornavirus life cycle by inducing a series of cytotoxic reactions to promote picornaviral replication and release [6-14]. The 2B protein has a highly conserved sequence, which can be exploited for viral detection [15-17], vaccine development [18-20], and RNA interference [21-25]. In addition, the $2 \mathrm{~B}$ protein exhibits a viroporin or viroporin-like activity, and thus, targeted drugs against viroporin could potentially target $2 \mathrm{~B}$ protein as a novel strategy to treat or prevent picornavirus infections. However, the detailed mechanism of action of the $2 \mathrm{~B}$ protein has not been elucidated to date. Therefore, here, we review the recent research data on the role of the $2 \mathrm{~B}$ protein in the picornaviral life cycle and discuss its possible application in antiviral therapy.

\section{Structure and Cellular Location of the Picornaviral 2B Protein}

The picornaviral 2B protein is a relatively short molecule, containing a maximum of two predicted putative transmembrane hydrophobic helices, along with N- and C-terminal domains, which are connected by a short stretch of amino acid residues. The $\alpha$-helix-turn- $\alpha$-helix sequence of the $2 \mathrm{~B}$ protein is the basis for forming a transmembrane pore through homo-multimerization and the major determinant of the $2 \mathrm{~B}$ protein function $[4,11,26-30]$. A computational approach has demonstrated that the EV 2B protein is a tetramer, and $2 \mathrm{~B}$ proteins with different orientations have different activities [31,32]. The $2 \mathrm{~B}$ protein belongs to the type II family of viroporins, which can be further divided into different types according to the number and orientation of the membrane-spanning domains (Figure 1). In type IIA viroporins, the $\mathrm{N}$ - and C-termini stretch to the organelle lumen, such as in the $2 \mathrm{~B}$ protein of CVB3 $[6,9,26,33]$, whereas the $\mathrm{N}$ - and C-termini of type IIB viroporins face the cytoplasmic matrix, such as in PV $[9,27,34]$ and FMDV $[7,14,28]$. In addition, the C-terminus of the HAV 2B protein has a viroporin-like activity [11].

Picornaviral 2B proteins target the membrane and form pores mainly through their transmembrane regions. The protein molecules are first inserted into the membrane individually and then self-interact and homo-oligomerize to form higher-order structures, which are important for the pore-forming activity, determined by the specific sequence and structure $[4,34,35]$. The majority of $2 \mathrm{~B}$ proteins are localized to organelles, with predominant co-localization with the Golgi apparatus and the endoplasmic reticulum (ER) in CVB3, PV, and HRV14 (Figure 1) [36]. The HRV16 and FMDV 2B proteins are mainly localized to the ER, whereas the EMCV 2B protein is not localized to either the Golgi complex or the ER $[28,36,37]$. Seggewiss et al. [38] found that the HAV 2B protein was not localized to the ER either but was involved in the amendment of the ER-Golgi apparatus intermediate compartment. Since the protein structure determines its ultimate function and $2 \mathrm{~B}$ proteins belonging to different viroporin species show both similarities and differences in their functions, much insight can be gained from research on the same viroporin $2 \mathrm{~B}$ protein and on different viroporins. 


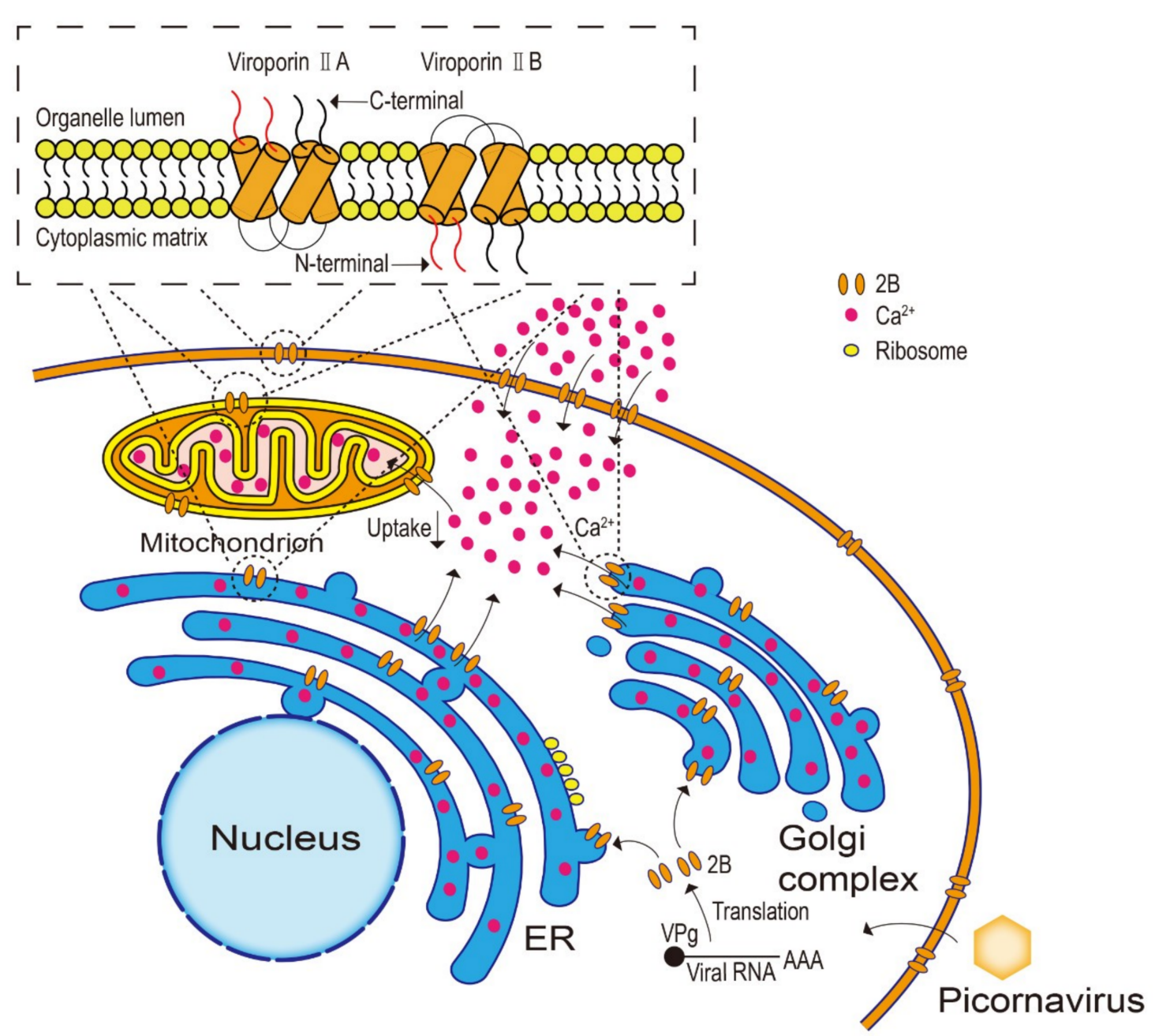

Figure 1. The structure and localization of 2B protein have effects on cell membrane permeability. Picornavirus infects the host cell, and then viral gene encodes $2 \mathrm{~B}$ proteins. The $2 \mathrm{~B}$ protein belongs to the type II family of viroporins, including two transmembrane hydrophobic helices which are the basis for forming a transmembrane pore that results in the changes in cell membrane permeability. In type IIA viroporins, the $\mathrm{N}$ - and $\mathrm{C}$-termini stretch to the organelle lumen, whereas the $\mathrm{N}$ - and C-termini of type II B viroporins face the cytoplasmic matrix. The majority of $2 \mathrm{~B}$ proteins are localized to organelles, with predominant co-localization with the Golgi apparatus and the endoplasmic reticulum (ER), resulting in an obvious decrease in $\mathrm{Ca}^{2+}$ of the ER and Golgi complex, along with a decrease in calcium uptake by the mitochondrion, and causing an influx of extracellular $\mathrm{Ca}^{2+}$.

\section{Biological Functions of the Picornaviral 2B Protein}

The $2 \mathrm{~B}$ protein can induce many cellular reactions, such as changing membrane permeability, regulating apoptosis and autophagy, and affecting host immune responses. These functions are all related to changes in ion concentrations, especially of calcium ions $\left(\mathrm{Ca}^{2+}\right)$. Therefore, here, we mostly focus on the role of $\mathrm{Ca}^{2+}$ in these $2 \mathrm{~B}$ protein activities.

\subsection{Change in Membrane Permeability}

A common feature of infection by animal viruses is the damage to the ion balance in host cells. The picornaviral 2B protein may change the membrane permeability of target cells, disturbing the ion balance, especially that of $\mathrm{Ca}^{2+}$, in organelles, such as the ER and the Golgi apparatus (Figure 1) [6,36,39]. The changes in membrane permeability, caused by the $2 \mathrm{~B}$ protein, have also been suggested to be regulated by the content of specific membrane phospholipids $[11,40]$. The $\mathrm{Ca}^{2+}$ are involved in the 
activation of enzymes in cells and play a crucial role in viral replication and other viral biological processes [41-43]. However, the role of the $2 \mathrm{~B}$ protein in $\mathrm{Ca}^{2+}$ homeostasis remains unclear.

Initial studies only indicated that host cells had elevated the $\mathrm{Ca}^{2+}$ levels, owing to the expression of the $2 B$ protein $[9,28,29,36,44-46]$, but the mechanism was not clarified. Since then, some researchers have proposed that the decrease in the concentration of $\mathrm{Ca}^{2+}$ stored in organelles triggers the opening of specific calcium ion channels on the plasma membrane of cells, causing an influx of extracellular $\mathrm{Ca}^{2+}$ [29]. This idea was supported by the findings that expression of the CVB3 and PV 2B proteins resulted in an obvious decrease in the $\mathrm{Ca}^{2+}$ concentration in the ER and Golgi complex, along with a decrease in calcium uptake by the mitochondria. Meanwhile, the increased $\mathrm{Ca}^{2+}$ level in the cytoplasm was suggested to be mainly due to the influx of extracellular $\mathrm{Ca}^{2+}[36,44,45]$. Similarly, the expression of the HRV 2B protein was shown to decrease the $\mathrm{Ca}^{2+}$ concentrations in the ER and Golgi apparatus, whereas the EMCV 2B protein only significantly reduced the $\mathrm{Ca}^{2+}$ concentration in the ER [36]. In contrast, other studies showed that expression of the HAV and FMDV 2B proteins elevated the cytoplasmic $\mathrm{Ca}^{2+}$ level but did not alter the level of stored $\mathrm{Ca}^{2+}$ in organelles, such as the ER and Golgi complex $[28,36]$. Taken together, these studies suggest that there are different mechanisms by which $2 \mathrm{~B}$ proteins affect the $\mathrm{Ca}^{2+}$ concentrations, depending on the virus type. Furthermore, it is unknown whether $\mathrm{Ca}^{2+}$ directly pass through the channel formed by the $2 \mathrm{~B}$ protein. Pham et al. [47] demonstrated, using a planar lipid bilayer and liposome patch-clamp electrophysiological technique, that the rotavirus non-structural protein 4 (NSP4) viroporin region acts as a $\mathrm{Ca}^{2+}$ conduction channel.

Although there is currently no direct evidence that the $2 \mathrm{~B}$ protein can directly induce the observed changes in the $\mathrm{Ca}^{2+}$ concentration in host cells upon infection, the above-reviewed studies suggest an association, and the mechanism requires further investigation. Given the importance of $\mathrm{Ca}^{2+}$ signaling for numerous cellular processes, further studies on picornaviral 2B protein function should include determination of the $\mathrm{Ca}^{2+}$ concentration, which may provide more insight into the detailed function of the $2 \mathrm{~B}$ protein. In particular, the $2 \mathrm{~B}$ protein may change the $\mathrm{Ca}^{2+}$ concentration to regulate autophagy and apoptosiswhich are distinct cell death mechanisms controlled by the virus to effectively evade the host immunity, thereby promoting viral replication and release [48-52].

\subsection{Regulation of Host Cell Apoptosis and Autophagy}

Picornaviruses can form new cytoplasmic vesicles by inducing membrane remodeling, thereby promoting their own proliferation $[39,53,54]$. The $2 \mathrm{~B}$ protein is capable of binding to the membrane and inducing target membrane remodeling to form a unique membrane structure that can serve as a viral replication site. This site, known as the viroplasm, is generated from the ER to accumulate all of the cellular components required for viral replication (Figure 2) $[13,39,54-56]$. The viroplasm is also the main membrane source of autophagy [54,57].

The CVB3 2B protein is dependent on its transmembrane hydrophobic region to induce autophagy [8], which may be related to alterations in membrane permeability, especially with regard to the $\mathrm{Ca}^{2+}$ concentration. Moreover, at an early stage of FMDV cell infection, the virus specifically recognizes and binds to the cell surface receptors, and the $2 \mathrm{~B}$ protein rapidly upregulates the autophagy pathway, leading to punctate aggregation of a large number of autophagy marker proteins, such as the microtubule-associated protein 1 light chain 3 (MAP1-LC3) [28,58]. In addition, rotavirus encodes the NSP4 viroporin, which releases the ER-stored $\mathrm{Ca}^{2+}$ into the cytoplasm, thereby activating the $\mathrm{Ca}^{2+} /$ calmodulin-dependent kinase kinase- $\beta$ (CaMKK- $\beta$ ) signaling pathway, leading to autophagy (Figure 2) [59]. Further, CVB4 induces autophagy in a calpain-dependent manner, causing an accumulation of LC3 lipids and autophagosomes [60]. Considering the ability of the 2B protein to alter cellular calcium homeostasis, along with its viroporin-like activity, it is feasible that the $2 \mathrm{~B}$ protein may regulate autophagy mainly by changing the $\mathrm{Ca}^{2+}$ concentration.

The $2 \mathrm{~B}$ protein has also been shown to regulate apoptosis through the endogenous pathway, which can be divided into ER stress and the mitochondrial pathway, providing another potential mechanism of bypassing the host immune response to facilitate infection $[32,37,44,45,48]$. The $\mathrm{Ca}^{2+}$ 
plays a pivotal role in ER stress-dependent apoptosis by regulating the flow between the ER and the mitochondria $[45,61]$. Excessive mitochondrial uptake of $\mathrm{Ca}^{2+}$ exerts a cytotoxic effect because a high $\mathrm{Ca}^{2+}$ concentration can open numerous mitochondrial transition pores, increase mitochondrial permeability, and destroy the mitochondrial outer membrane; consequently, cytochrome $\mathrm{c}$ and other proapoptotic factors are released, leading to apoptosis (Figure 2) [9,32,44,45,62]. The CVB3 2B protein was shown to inhibit caspase activation and cell death induced by actinomycin $\mathrm{D}$ and cycloheximide by regulating the intracellular $\mathrm{Ca}^{2+}$ concentration $[44,45]$. Additionally, the $2 \mathrm{~B}$ protein of HRV16 induced an ER stress response, accompanied by an increased expression of cleaved caspase-3 and CCAAT-enhancer-binding protein homologous protein (CHOP), which might have also involved a change in the $\mathrm{Ca}^{2+}$ level [37]. Collectively, these results suggest that the $2 \mathrm{~B}$ protein may regulate apoptosis by altering calcium homeostasis. Furthermore, the 2B protein can regulate apoptosis through the mitochondrial pathway. Madan et al. [32] showed that the PV 2B protein interacted with the mitochondria and altered the mitochondrial morphology, in addition to the release of cytochrome $C$ after the PV 2B gene expression. Cong et al. [63] reported that the EV71 2B protein was localized to the mitochondria and induced apoptosis by directly activating the proapoptotic B-cell lymphoma 2-associated X (BAX) protein, without a significant uptake of $\mathrm{Ca}^{2+}$ by the mitochondria. Therefore, the activation of the mitochondrial apoptotic pathway and subsequent apoptosis, induced by the EV71 2B protein, may not involve $\mathrm{Ca}^{2+}$ signaling. Collectively, picornaviral $2 \mathrm{~B}$ proteins can induce cell death in a variety of ways, with $\mathrm{Ca}^{2+}$ playing an important role in most of these mechanisms.

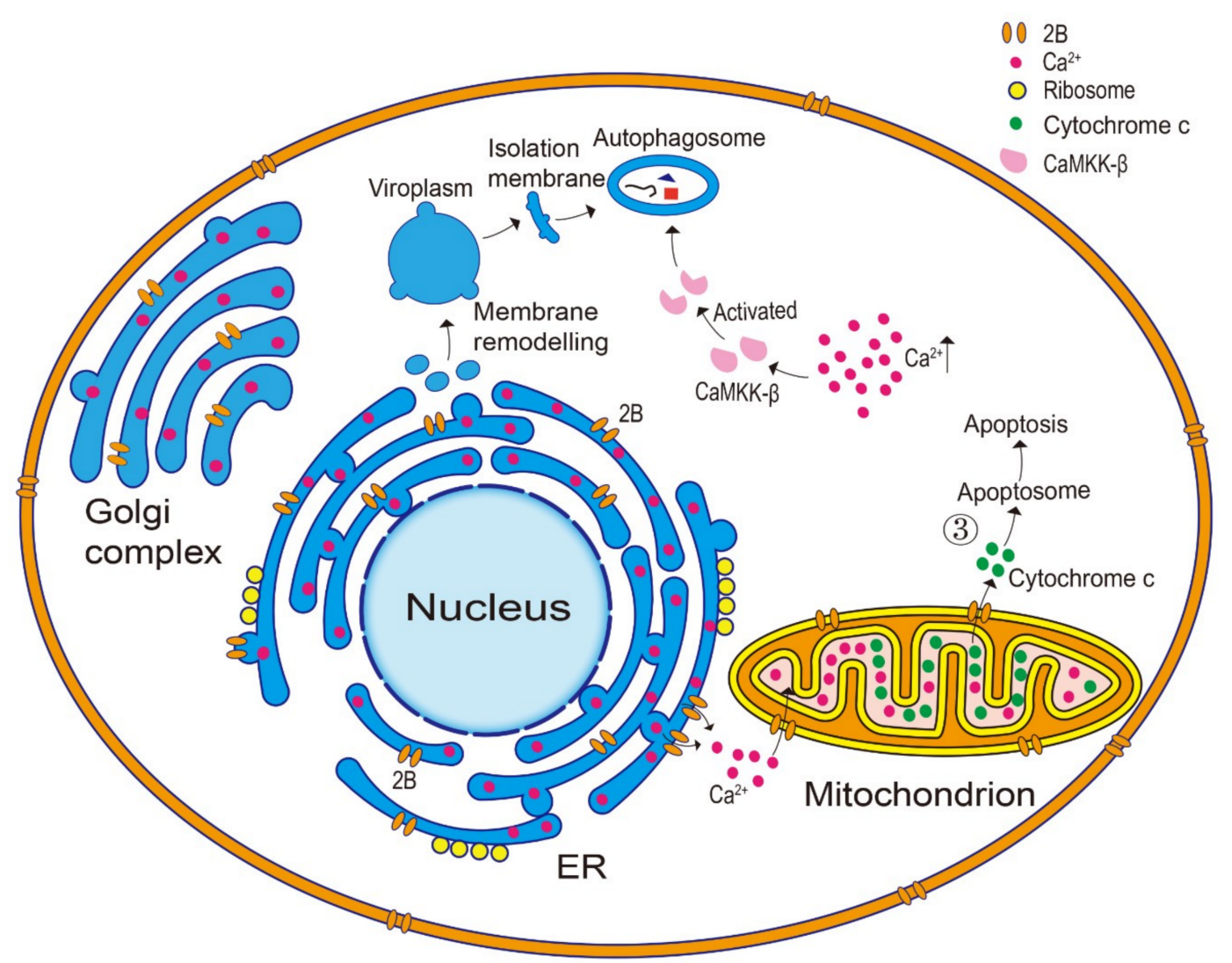

Figure 2. $2 \mathrm{~B}$ protein regulates autophagy and apoptosis. The $2 \mathrm{~B}$ protein induces target membrane remodeling to form the viroplasm, which is generated from the endoplasmic reticulum (ER). The isolation membrane is produced by the viroplasm. Activation of the $\mathrm{Ca}^{2+} /$ calmodulin-dependent kinase kinase- $\beta$ (CaMKK- $\beta$ ) signal pathway is due to an increased intracellular calcium concentration. Furthermore, mitochondrion takes up $\mathrm{Ca}^{2+}$ from the ER, thereby cytochrome cis released, leading to apoptosis. 


\subsection{Effect on the Host Immune Response}

The host immune system is an important line of defense against pathogens, and pathogens can affect the immune system in a variety of ways. The $2 \mathrm{~B}$ protein mainly affects the host immune response through inflammasome activation and by direct antagonism of the host immune response. Recognition of pathogens by the immune system is mainly mediated by pathogen-associated molecular pattern receptors, known as pattern recognition receptors, including nucleotide-binding oligomerization domain (NOD)-like receptors (NLRs), retinoic acid-inducible gene-I (RIG-I)-like helicases, and pyrin domain-containing 3 (NLRP3) [64-66].

Activation of NLRP3 inflammasome occurs during a period of changes in ion concentrations [67,68]. The NLRP3 belongs to the NLR family of inflammasomes and causes interleukin (IL)-1 $\beta$ and IL-18 secretion via caspase-1 activation [67]. The EMCV, PV, EV71, and HRV 2B proteins all activate the NLRP3 inflammasome but use distinct mechanisms [12,69]. The HRV and EMCV 2B proteins can stimulate the NLRP3 inflammasome pathway to activate caspase-1, which catalyzes the proteolysis of pro-IL-1 $\beta$ to IL-1 $\beta$, leading to its secretion from across the plasma membrane by inducing a $\mathrm{Ca}^{2+}$ efflux from intracellular storage (Figure 3) [12,69]. Wang et al. [70] found that CVB3-infected cells induced the NLRP3 activation in association with a $\mathrm{K}^{+}$efflux. The influenza virus M2 protein, which is also a viroporin, is capable of transporting $\mathrm{Na}^{+}$and $\mathrm{K}^{+}$, resulting in activation of the NLRP3 inflammasome [71,72]. Since the CVB3 2B protein acts as a viroporin and can disrupt the intracellular ion balance $[36,46]$, it has been speculated that the induction of NLRP3 activation in CVB3-infected cells may be related to the $2 \mathrm{~B}$ protein.

In addition to activating the inflammasome, the $2 \mathrm{~B}$ protein also antagonizes the host immune response. Both in vitro and in vivo studies have suggested that inhibition of protein trafficking would effectively allow viral evasion of the host immune response (Figure 3) [73-75]. Moreover, inhibition of protein transport may be related to changes in the $\mathrm{Ca}^{2+}$ concentration [46]. Similar to the CVB3 2B protein, the 2B proteins of PV, HRV16 and HRV14, were shown to significantly inhibit the protein transport through the Golgi complex, whereas the HAV, FMDV, and EMCV 2B proteins did not inhibit the protein transport $[36,46,76]$. The FMDV $2 B$ and $2 C$ proteins did not block protein secretion, whereas the transport of proteins from the ER to the Golgi complex were blocked by the FMDV 2BC protein, and this effect was reproduced upon co-expression of the $2 C$ and $2 B$ genes $[7,77]$. Collectively, these findings suggest that the $2 \mathrm{~B}$ protein may participate in a viral evasion of the host immune response, mainly by inhibiting protein transport. 


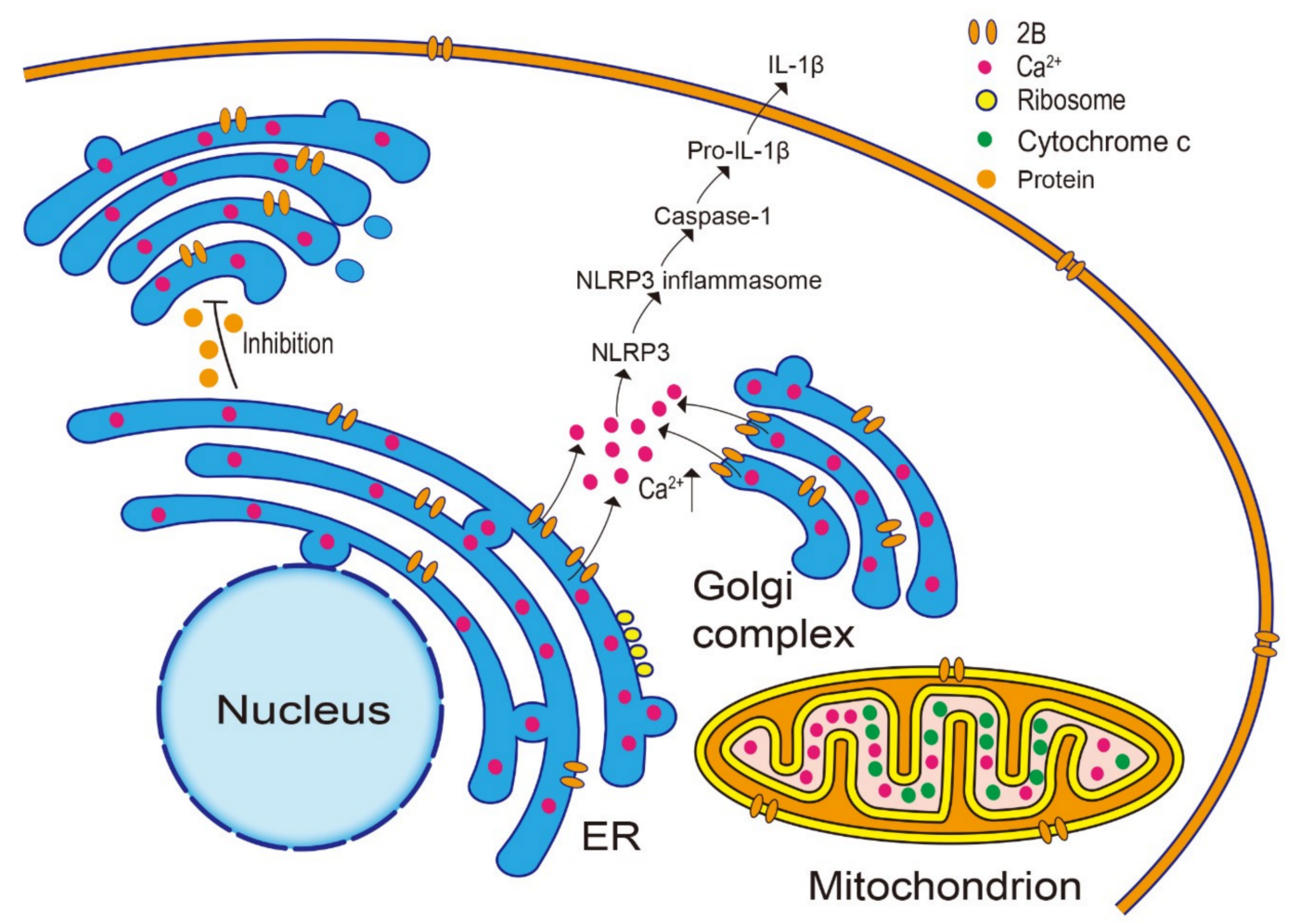

Figure 3. $2 \mathrm{~B}$ protein affects the host immune response. The $2 \mathrm{~B}$ protein can stimulate the NLRP3 inflammasome pathway to activate caspase- 1 , which catalyzes the proteolysis of pro-IL- $1 \beta$ to IL- $1 \beta$, which leads to their secretion across the plasma membrane by inducing a $\mathrm{Ca}^{2+}$ efflux from intracellular storage. Moreover, the $2 \mathrm{~B}$ protein inhibits protein transport through the Golgi protein which may be effective to evade the host immune response.

The $2 \mathrm{~B}$ protein has also been suggested to facilitate the viral evasion of the host immune response through other means. Thus, the 2B protein antagonizes RIG-I-mediated antiviral responses by inhibiting the expression of RIG-I as an FMDV-specific reaction [14]. The RNA helicase LGP2 (also known as DExH-box helicase 58, DHX58) is a crucial factor involved in the host antiviral immune response [78]. The FMDV leader protein (Lpro), $3 \mathrm{C}$ protein, and the $2 \mathrm{~B}$ protein have the ability to induce a decrease in LGP2 protein expression [79]. In addition, PV 2B variants were shown to inhibit the antiviral interferon (IFN) system [80], whereas the HAV 2B protein inhibited the synthesis of IFN- $\beta$ by affecting the mitochondrial antiviral signaling protein activity, thereby antagonizing the host immune response [81]. Collectively, these evidences indicate that picornaviral 2B proteins can affect the host immune response, thereby promoting viral amplification or the release of viral particles.

\section{Potential Applications of Targeting the Picornaviral 2B Protein}

As discussed above, picornaviral 2B proteins have a viroporin or viroporin-like activity and play an important role in the picornaviral life cycle. Therefore, many common applications targeting viroporins may be translatable to those targeting $2 \mathrm{~B}$ proteins. In addition, the $2 \mathrm{~B}$ protein may serve as a new target for the development of antiviral drugs. Thus, further studies on the structure and function of the $2 \mathrm{~B}$ protein might open up new avenues for the prevention and control of picornaviruses.

\subsection{Detection of Picornaviruses}

Owing to its highly conserved sequence, the use of the $2 B$ gene as a marker could effectively improve the accuracy of virus detection. Li et al. [15] designed primers and TaqMan probes, based on the $2 B$ and $3 D$ regions, which were successfully used in real-time polymerase chain reaction to accurately detect and quantify FMDV during infection and replication. In addition, Wang et al. [16] 
developed a lateral-flow detection system, which could rapidly and easily detect FMDV using the $2 B$ gene. In addition to gene-based detection, the virus could be detected using a $2 \mathrm{~B}$ antibody. Biswal et al. [17] used an indirect enzyme-linked immunoassay based on a recombinant 2B protein to detect antibodies specific for FMDV. This method can be applied not only to FMDV but also to other picornaviruses, including CVB3 and EV71.

\subsection{Development of Vaccines}

Given the significant threat that picornaviruses pose to humans and animals, resulting in enormous economic damage to the livestock industry, development of picornavirus vaccines is of great significance. Although inactivated virus vaccines can offer effective prevention, there are associated residual risk issues, including incomplete virus inactivation and escape during the vaccine production process [82-84]. Therefore, genetically engineered vaccines are considered more suitable options to overcome these shortcomings of inactivated viral vaccines. The EV VP1 protein is located outside the viral membrane and is thus exposed to the greatest amount of immune stress. Accordingly, VP1 shows an extreme serological variability, thus providing the most reliable molecular epidemiological information. Consequently, the VP1 region of EV71 has become a focus of vaccine research for picornavirus infections [84]. However, DNA constructs containing the VP1 gene of EV71 showed low levels of antigenicity. Therefore, there is still a need to develop an effective adjuvant strategy to increase the antigenicity. One possibility in this regard is the use of recombinant vaccines incorporating the $2 B$ gene to enhance the efficacy of vaccines.

At present, applications of the $2 B$ gene in recombinant vaccines have mainly concentrated on FMDV. The addition of a $2 B$ fragment to a vaccine designed with VP1 as the core has been shown to effectively enhance the vaccine efficacy [18-20] and reduce the dose and side effects [20]. These effects may be similar to those leading to a greater efficacy of the adenoviral vector vaccine fused to the FMDV 2B protein against serotype $\mathrm{O}$, which is associated with the induction of specific $\mathrm{CD} 4^{+}$and $\mathrm{CD} 8^{+}$ protective $\mathrm{T}$ cell responses [85]. Therefore, future designs of other picornaviral genetically engineered vaccines would benefit from the addition of the $2 B$ gene to increase the vaccine efficacy, including the addition of the $2 B$ gene to a genetically engineered $E V$ vaccine with the VP1 gene as the core.

\subsection{Drug Development Strategy for Picornavirus Treatment}

Since viroporin plays an important role in all life stages of the virus, it is an attractive antiviral therapeutic target, and there have been great breakthroughs in this regard. By contrast, research and development of drugs targeting the $2 \mathrm{~B}$ protein are relatively delayed. Since $2 \mathrm{~B}$ proteins have a viroporin or viroporin-like activity, screening for anti-picornavirus drugs among existing viroporin-targeting drugs may be a viable approach.

There are four main types of inhibitors of viroporin activity, including adamantane, amiloride, alkyl iminosugar, and spirane amine [86]. Adamantane (amantadine and rimantadine) inhibits the M2 channel of influenza A virus by destroying the transmembrane network of hydrogen-bonded water molecules, thereby inhibiting the viral amplification [87]. In BHK-21 cells infected with FMDV, the virus titer gradually decreased with an increase in amantadine concentration, which may have been due to abrogation of the pore-forming activity of the $2 \mathrm{~B}$ protein and ultimate inhibition of FMDV replication [28]. However, clinical trials showed that amantadine was not only selective for specific resistance mutations in hepatitis C virus (HCV) p7 [88], but also caused a rapid emergence of amantadine-resistant variants of influenza A virus during monotherapy for influenza [89]. Amiloride is a composite of two drugs, 5-(N,N-hexamethylene) amiloride and a novel inhibitor, BIT225, targeting HCV p7 and HIV-1 Vpu, which can together block the viroporin ion channel activity or prevent ion channel formation, resulting in a potent antiviral effect [90-93]. The alkyl iminosugar inhibits the formation of ion channels by targeting the HCV p7 viroporin [94]. Finally, spirane amines, such as BL-1743, also inhibit the influenza A virus M2 protein, with an antiviral mechanism similar to that of amantadine [95]. 
There are also other drugs that act as viroporin inhibitors, including 1,3-dibenzyl-5( $2 H-1,2,3,4-$ tetraazol-5-yl) hexahydropyrimidine (CD), $N$-(1-phenylethyl)-2-[4-(phenylsulfonyl)-1-piperazinyl]-4quinazolinamine (LDS25), and 6-methyl-1,3,8-trihydroxyanth-raquinone (Emodin), among others $[88,96,97]$. The mechanism of action of these viroporin inhibitors is based on the inhibition of the viroporin channel activity. Therefore, these drugs may have the potential to be applied for the treatment of picornavirus infections by targeting the $2 B$ gene. However, this application will require further detailed investigations and drug screening. Nevertheless, the $2 \mathrm{~B}$ protein has the potential to widen the range of antiviral treatment strategies.

Furthermore, specific degradation of complementary mRNA can be triggered by small interfering RNAs (siRNAs) or folded short hairpin RNAs (shRNAs) [98], which can be explored as an RNA interference strategy, a relatively novel technology that has already been applied to treat many important pathogens, including HIV-1, hepatitis B virus, and herpes simplex virus [99-101]. Currently, shRNAs targeting the highly conserved $2 B$ gene sequence are widely used in picornavirus research, including FMDV [21,25], EMCV [23], and CVB3 [24], and significant experimental viral suppression has been achieved. Basically, RNA interference against $2 B$ gene affects the stability and integrity of the whole viral genome. The high nucleotide sequence conservation makes the $2 B$ gene an attractive target for RNA interference, which may potentially be effective against multiple picornavirus types, and open the door for additional siRNA drugs.

To date, there have been few studies specifically focusing on inhibitors of the $2 \mathrm{~B}$ protein. Xie et al. [102] found that 4,4'-diisothiocyano-2, $2^{\prime}$-stilbenedisulfonic acid (DIDS) blocked a chloridedependent current, mediated by the EV71 2B protein, and suppressed viral amplification. However, further research is needed to uncover the underlying mechanism. Despite the many challenges in drug development, new technologies such as Fourier-transform infrared spectroscopy and design of molecular dynamics analogs, as well as cryo-electron microscopy and spectroscopy, are expected to greatly contribute to the development of antiviral drugs.

\section{Future Perspectives and Conclusion}

Recent studies have gradually clarified the function and the potential of the 2B protein, along with increasingly recognizing its importance in the viral life cycle. However, there are still some challenges to overcome in investigations of the picornaviral 2B protein. In particular, its strong hydrophobicity makes it difficult to achieve soluble expression. Ao et al. [28] conjugated the small ubiquitin-like modifier (SUMO) protein to the N-terminus of the FMDV 2B protein and successfully achieved soluble expression. Therefore, this method can be tested for other picornaviral 2B proteins. Moreover, the detailed molecular mechanism of the action of the $2 \mathrm{~B}$ protein requires further study, along with the identification of interactions of $2 \mathrm{~B}$ protein with host proteins, to better understand the role of the $2 \mathrm{~B}$ protein in the pathogenesis of picornaviruses. In murine cells, the 2B protein was suggested to react with host proteins to promote rhinovirus proliferation [103]. Using a yeast two-hybrid system, the FMDV 2B protein was found to interact with the host elongation factor $1 \gamma$ (EEF1G), and mislocalization of EEF1G demonstrated that the EEF1G deletion affected the synthesis of membrane proteins [104,105]. Although a yeast two-hybrid system is a common laboratory protein-screening technique, it has a low success rate and is time-consuming. Alternatively, affinity purification-mass spectrometry can be used to overcome these shortcomings, which has already been widely used in studies on Dengue, Zika, and Ebola viruses [106,107].

At present, the development of antiviral drugs against viroporins is focused on three aspects, including viroporin and membrane fusion inhibitors, ion channel inhibitors, and targeted viroporin antibodies [9]. With respect to the biological function of the 2B protein, antiviral drugs targeting the 2B protein could be designed based on the following three approaches: broad-spectrum screening for anti-picornavirus drugs among existing viroporin inhibitors, screening for $2 \mathrm{~B}$ protein and membrane fusion inhibitors, and screening for $2 \mathrm{~B}$ protein pore activity inhibitors. As discussed herein, the most important basis for the function of the $2 \mathrm{~B}$ protein is that it can be polymerized into pores, thereby 
changing the permeability of the membrane. Therefore, the design of drugs targeting 2B protein should be based on inhibiting polymerization of the $2 \mathrm{~B}$ protein into pores, thereby reducing its effects on cellular ion homeostasis. However, these designs first require detailed determination of the refined atomic structure of the $2 \mathrm{~B}$ protein, along with the expansion of screening techniques and applications of meticulous medicinal chemistry.

Furthermore, to develop better antiviral drugs, it will be necessary to elucidate the exact role of the $2 \mathrm{~B}$ protein channel in the viral life cycle. Thus, the main points of focus for research on the structure and function of the $2 \mathrm{~B}$ protein toward ultimate drug development are: (1) mechanism of increasing membrane permeability to disturb the ion balance, (2) regulation of autophagy and apoptosis, (3) inhibition of the host immune response, and (4) promotion of viral replication and release. Taken together, as research aimed at further elucidation of the role of the $2 \mathrm{~B}$ protein progresses, along with the adoption of new technologies, it is expected that more strategies will come to light for antiviral drug development and disease control.

Author Contributions: Z.L., Z.Z. and Z.J. wrote the manuscript; Q.L. and X.H. revised for its integrity and accuracy; Q.L. approved the final version of this manuscript and takes responsibility for its contents.

Funding: This study was supported by the National Natural Science Foundation of China (31760261 and 31660035), the Science and Technology Research project of Jiangxi Provincial Education Department (60224), National Innovation and Entrepreneurship Program for College Students (20190403031 and 20190403070) and key projects of the Jiangxi Natural Science Foundation (20171ACB20003).

Conflicts of Interest: The authors declare no conflicts of interest.

\section{Abbreviations}

\begin{tabular}{ll} 
CV & coxsackievirus \\
PV & poliovirus \\
EMCV & encephalomyocarditis virus \\
EV & enterovirus \\
FMDV & foot-and-mouth disease virus \\
HRV & human rhinovirus \\
NCR & noncoding region \\
ER & endoplasmic reticulum \\
MAP1-LC3 & microtubule-associated protein 1 light chain 3 \\
NLRP3 & pyrin domain-containing 3 \\
NSP4 & non-structural protein 4 \\
CaMKK- $\beta$ & calmodulin-dependent kinase kinase- $\beta$ \\
RIG-I & retinoic acid-inducible gene-I \\
shRNA & short hairpin RNA \\
siRNA & small interfering RNA \\
EEF1G & elongation factor $1 \gamma$ \\
HAV & hepatitis A virus \\
CHOP & CCAAT-enhancer-binding protein homologous protein \\
BAX & B-cell lymphoma 2-associated X \\
NOD & nucleotide-binding oligomerization domain \\
NLR & NOD-like receptor \\
IL & interleukin \\
DHX58 & DExH-box helicase 58 \\
IFN & interferon \\
HCV & hepatitis C virus \\
SUMO & small ubiquitin-like modifier \\
& \\
\hline
\end{tabular}




\section{References}

1. Zell, R.; Delwart, E.; Gorbalenya, A.E.; Hovi, T.; King, A.M.Q.; Knowles, N.J.; Lindberg, A.M.; Pallansch, M.A.; Palmenberg, A.C.; Reuter, G.; et al. ICTV Virus Taxonomy Profile: Picornaviridae. J. Gen. Virol. 2017, 98, 2421-2422. [CrossRef]

2. Tuthill, T.J.; Groppelli, E.; Hogle, J.M.; Rowlands, D.J. Picornaviruses. Curr. Top. Microbiol. Immunol. 2010, 343, 43-89. [PubMed]

3. Stanway, G.; Joki-Korpela, P.; Hyypia, T. Human parechoviruses-biology and clinical significance. Rev. Med. Virol. 2000, 10, 57-69. [CrossRef]

4. Martinez-Gil, L.; Mingarro, I. Viroporins, Examples of the Two-Stage Membrane Protein Folding Model. Viruses 2015, 7, 3462-3482. [CrossRef] [PubMed]

5. Nieva, J.L.; Madan, V.; Carrasco, L. Viroporins: Structure and biological functions. Nat. Rev. Microbiol. 2012, 10, 563-574. [CrossRef] [PubMed]

6. Sanchez-Martinez, S.; Madan, V.; Carrasco, L.; Nieva, J.L. Membrane-active peptides derived from picornavirus 2B viroporin. Curr. Protein Pept. Sci. 2012, 13, 632-643. [CrossRef] [PubMed]

7. Gladue, D.P.; Largo, E.; de la Arada, I.; Aguilella, V.M.; Alcaraz, A.; Arrondo, J.L.R.; Holinka, L.G.; Brocchi, E.; Ramirez-Medina, E.; Vuono, E.A.; et al. Molecular Characterization of the Viroporin Function of Foot-and-Mouth Disease Virus Nonstructural Protein 2B. J. Virol. 2018, 92, e01360-18. [CrossRef] [PubMed]

8. Wu, H.; Zhai, X.; Chen, Y.; Wang, R.; Lin, L.; Chen, S.; Wang, T.; Zhong, X.; Wu, X.; Wang, Y.; et al. Protein 2B of Coxsackievirus B3 Induces Autophagy Relying on Its Transmembrane Hydrophobic Sequences. Viruses 2016, 8, 131. [CrossRef]

9. Ao, D.; Sun, S.Q.; Guo, H.C. Topology and biological function of enterovirus non-structural protein 2B as a member of the viroporin family. Vet. Res. 2014, 45, 87. [CrossRef]

10. Roulin, P.S.; Murer, L.P.; Greber, U.F. A Single Point Mutation in the Rhinovirus 2B Protein Reduces the Requirement for Phosphatidylinositol 4-Kinase Class III Beta in Viral Replication. J. Virol. 2018, 92, e01462-18. [CrossRef] [PubMed]

11. Shukla, A.; Dey, D.; Banerjee, K.; Nain, A.; Banerjee, M. The C-terminal region of the non-structural protein 2B from Hepatitis A Virus demonstrates lipid-specific viroporin-like activity. Sci Rep. 2015, 5, 15884. [CrossRef] [PubMed]

12. Ito, M.; Yanagi, Y.; Ichinohe, T. Encephalomyocarditis Virus Viroporin 2B Activates NLRP3 Inflammasome. PLoS Pathog. 2012, 8, e1002857. [CrossRef] [PubMed]

13. Vives-Adrian, L.; Garriga, D.; Buxaderas, M.; Fraga, J.; Pereira, P.J.; Macedo-Ribeiro, S.; Verdaguer, N. Structural basis for host membrane remodeling induced by protein 2B of hepatitis A virus. J. Virol. 2015, 89, 3648-3658. [CrossRef] [PubMed]

14. Zhu, Z.; Wang, G.; Yang, F.; Cao, W.; Mao, R.; Du, X.; Zhang, X.; Li, C.; Li, D.; Zhang, K.; et al. Foot-and-Mouth Disease Virus Viroporin 2B Antagonizes RIG-I-Mediated Antiviral Effects by Inhibition of Its Protein Expression. J. Virol. 2016, 90, 11106-11121. [CrossRef] [PubMed]

15. Li, Y.; Huang, X.; Xia, B.; Zheng, C. Development and validation of a duplex quantitative real-time RT-PCR assay for simultaneous detection and quantitation of foot-and-mouth disease viral positive-stranded RNAs and negative-stranded RNAs. J. Virol. Methods 2009, 161, 161-167. [CrossRef] [PubMed]

16. Wang, H.M.; Zhao, G.M.; Hou, P.L.; Yu, L.; He, C.Q.; He, H.B. Rapid detection of foot-and-mouth disease virus using reverse transcription recombinase polymerase amplification combined with a lateral flow dipstick. J. Virol. Methods 2018, 261, 46-50. [CrossRef]

17. Biswal, J.K.; Jena, S.; Mohapatra, J.K.; Bisht, P.; Pattnaik, B. Detection of antibodies specific for foot-and-mouth disease virus infection using indirect ELISA based on recombinant nonstructural protein 2B. Arch. Virol. 2014, 159, 1641-1650. [CrossRef]

18. Pena, L.; Moraes, M.P.; Koster, M.; Burrage, T.; Pacheco, J.M.; Segundo, F.D.; Grubman, M.J. Delivery of a foot-and-mouth disease virus empty capsid subunit antigen with nonstructural protein 2B improves protection of swine. Vaccine 2008, 26, 5689-5699. [CrossRef]

19. Barrera, J.; Brake, D.A.; Schutta, C.; Ettyreddy, D.; Kamicker, B.J.; Rasmussen, M.V.; Bravo de Rueda, C.; Zurita, M.; Pisano, M.; Hurtle, W.; et al. Versatility of the adenovirus-vectored foot-and-mouth disease vaccine platform across multiple foot-and-mouth disease virus serotypes and topotypes using a vaccine dose representative of the AdtA24 conditionally licensed vaccine. Vaccine 2018, 36, 7345-7352. [CrossRef] 
20. Diaz-San Segundo, F.; Dias, C.C.; Moraes, M.P.; Weiss, M.; Perez-Martin, E.; Salazar, A.M.; Grubman, M.J.; de Los Santos, T. Poly ICLC increases the potency of a replication-defective human adenovirus vectored foot-and-mouth disease vaccine. Virology 2014, 468-470, 283-292. [CrossRef]

21. Jiao, Y.; Gong, X.; Du, J.; Liu, M.; Guo, X.; Chen, L.; Miao, W.; Jin, T.; Chang, H.; Zeng, Y.; et al. Transgenically mediated shRNAs targeting conserved regions of foot-and-mouth disease virus provide heritable resistance in porcine cell lines and suckling mice. Vet. Res. 2013, 44, 47. [CrossRef] [PubMed]

22. Liu, M.; Chen, W.; Ni, Z.; Yan, W.; Fei, L.; Jiao, Y.; Zhang, J.; Du, Q.; Wei, X.; Chen, J.; et al. Cross-inhibition to heterologous foot-and-mouth disease virus infection induced by RNA interference targeting the conserved regions of viral genome. Virology 2005, 336, 51-59. [CrossRef] [PubMed]

23. Jia, H.; Ge, X.; Guo, X.; Yang, H.; Yu, K.; Chen, Z.; Chen, Y.; Cha, Z. Specific small interfering RNAs-mediated inhibition of replication of porcine encephalomyocarditis virus in BHK-21 cells. Antivir. Res. 2008, 79, 95-104. [CrossRef] [PubMed]

24. Yao, H.L.; Zhang, Y.D.; He, F.; Wang, C.H.; Xiao, Z.H.; Zou, J.Z.; Wang, F.; Liu, Z.W. Short hairpin RNA targeting 2B gene of coxsackievirus B3 exhibits potential antiviral effects both in vitro and in vivo. BMC Infect. Dis. 2012, 12, 177. [CrossRef] [PubMed]

25. Xu, Y.F.; Shen, H.Y.; Zhao, M.Q.; Chen, L.J.; Li, Y.G.; Liao, M.; Jia, J.T.; Lv, Y.R.; Yi, L.; Chen, J.D. Adenovirus-vectored shRNAs targeted to the highly conserved regions of VP1 and 2B in tandem inhibits replication of foot-and-mouth disease virus both in vitro and in vivo. J. Virol. Methods 2012, 181, 51-58. [CrossRef] [PubMed]

26. de Jong, A.S.; Wessels, E.; Dijkman, H.B.; Galama, J.M.; Melchers, W.J.; Willems, P.H.; van Kuppeveld, F.J. Determinants for membrane association and permeabilization of the coxsackievirus $2 \mathrm{~B}$ protein and the identification of the Golgi complex as the target organelle. J. Biol. Chem. 2003, 278, 1012-1021. [CrossRef] [PubMed]

27. Agirre, A.; Barco, A.; Carrasco, L.; Nieva, J.L. Viroporin-mediated membrane permeabilization. Pore formation by nonstructural poliovirus 2B protein. J. Biol. Chem. 2002, 277, 40434-40441. [CrossRef] [PubMed]

28. Ao, D.; Guo, H.C.; Sun, S.Q.; Sun, D.H.; Fung, T.S.; Wei, Y.Q.; Han, S.C.; Yao, X.P.; Cao, S.Z.; Liu, D.X.; et al. Viroporin Activity of the Foot-and-Mouth Disease Virus Non-Structural 2B Protein. PLoS ONE 2015, 10, e0125828. [CrossRef]

29. van Kuppeveld, F.J.; Hoenderop, J.G.; Smeets, R.L.; Willems, P.H.; Dijkman, H.B.; Galama, J.M.; Melchers, W.J. Coxsackievirus protein $2 \mathrm{~B}$ modifies endoplasmic reticulum membrane and plasma membrane permeability and facilitates virus release. EMBO J. 1997, 16, 3519-3532. [CrossRef]

30. Jecht, M.; Probst, C.; Gauss-Muller, V. Membrane permeability induced by hepatitis A virus proteins $2 \mathrm{~B}$ and 2BC and proteolytic processing of HAV 2BC. Virology 1998, 252, 218-227. [CrossRef]

31. Patargias, G.; Barke, T.; Watts, A.; Fischer, W.B. Model generation of viral channel forming $2 B$ protein bundles from polio and coxsackie viruses. Mol. Membr. Biol. 2009, 26, U309-U348. [CrossRef] [PubMed]

32. Madan, V.; Sanchez-Martinez, S.; Carrasco, L.; Nieva, J.L. A peptide based on the pore-forming domain of pro-apoptotic poliovirus 2B viroporin targets mitochondria. Biochim. Biophys. Acta 2010, 1798, 52-58. [CrossRef] [PubMed]

33. van Kuppeveld, F.J.; Galama, J.M.; Zoll, J.; van den Hurk, P.J.; Melchers, W.J. Coxsackie B3 virus protein 2B contains cationic amphipathic helix that is required for viral RNA replication. J. Virol. 1996, 70, 3876-3886. [PubMed]

34. Nieva, J.L.; Agirre, A.; Nir, S.; Carrasco, L. Mechanisms of membrane permeabilization by picornavirus 2B viroporin. FEBS Lett. 2003, 552, 68-73. [CrossRef]

35. de Jong, A.S.; Melchers, W.J.; Glaudemans, D.H.; Willems, P.H.; van Kuppeveld, F.J. Mutational analysis of different regions in the coxsackievirus $2 \mathrm{~B}$ protein: Requirements for homo-multimerization, membrane permeabilization, subcellular localization, and virus replication. J. Biol. Chem. 2004, 279, 19924-19935. [CrossRef] [PubMed]

36. de Jong, A.S.; de Mattia, F.; Van Dommelen, M.M.; Lanke, K.; Melchers, W.J.G.; Willems, P.H.G.M.; van Kuppeveld, F.J.M. Functional analysis of picornavirus 2B proteins: Effects on calcium homeostasis and intracellular protein trafficking. J. Virol. 2008, 82, 3782-3790. [CrossRef] [PubMed]

37. Song, J.; Chi, M.; Luo, X.; Song, Q.; Xia, D.; Shi, B.; Han, J. Non-Structural Protein 2B of Human Rhinovirus 16 Activates Both PERK and ATF6 Rather Than IRE1 to Trigger ER Stress. Viruses 2019, 11, 133. [CrossRef] [PubMed] 
38. Seggewiss, N.; Kruse, H.V.; Weilandt, R.; Domsgen, E.; Dotzauer, A.; Paulmann, D. Cellular localization and effects of ectopically expressed hepatitis A virus proteins 2B, 2C, 3A and their intermediates 2BC, $3 \mathrm{AB}$ and 3ABC. Arch. Virol. 2016, 161, 851-865. [CrossRef] [PubMed]

39. Martinez-Gil, L.; Bano-Polo, M.; Redondo, N.; Sanchez-Martinez, S.; Nieva, J.L.; Carrasco, L.; Mingarro, I. Membrane Integration of Poliovirus 2B Viroporin. J. Virol. 2011, 85, 11315-11324. [CrossRef] [PubMed]

40. Agirre, A.; Lorizate, M.; Nir, S.; Nieva, J.L. Poliovirus $2 b$ insertion into lipid monolayers and pore formation in vesicles modulated by anionic phospholipids. Biochim. Biophys. Acta Biomembr. 2008, 1778, 2621-2626. [CrossRef] [PubMed]

41. Bozym, R.A.; Morosky, S.A.; Kim, K.S.; Cherry, S.; Coyne, C.B. Release of intracellular calcium stores facilitates coxsackievirus entry into polarized endothelial cells. PLoS Pathog. 2010, 6, e1001135. [CrossRef] [PubMed]

42. Bozym, R.A.; Patel, K.; White, C.; Cheung, K.H.; Bergelson, J.M.; Morosky, S.A.; Coyne, C.B. Calcium signals and calpain-dependent necrosis are essential for release of coxsackievirus B from polarized intestinal epithelial cells. Mol. Biol. Cell 2011, 22, 3010-3021. [CrossRef] [PubMed]

43. Decuypere, J.P.; Bultynck, G.; Parys, J.B. A dual role for $\mathrm{Ca}(2+)$ in autophagy regulation. Cell Calcium 2011, 50, 242-250. [CrossRef] [PubMed]

44. Campanella, M.; de Jong, A.S.; Lanke, K.W.; Melchers, W.J.; Willems, P.H.; Pinton, P.; Rizzuto, R.; van Kuppeveld, F.J. The coxsackievirus 2B protein suppresses apoptotic host cell responses by manipulating intracellular $\mathrm{Ca}^{2+}$ homeostasis. J. Biol. Chem. 2004, 279, 18440-18450. [CrossRef] [PubMed]

45. van Kuppeveld, F.J.; de Jong, A.S.; Melchers, W.J.; Willems, P.H. Enterovirus protein 2B po(u)res out the calcium: A viral strategy to survive? Trends Microbiol. 2005, 13, 41-44. [CrossRef] [PubMed]

46. de Jong, A.S.; Visch, H.J.; de Mattia, F.; van Dommelen, M.M.; Swarts, H.G.; Luyten, T.; Callewaert, G.; Melchers, W.J.; Willems, P.H.; van Kuppeveld, F.J. The coxsackievirus 2B protein increases efflux of ions from the endoplasmic reticulum and Golgi, thereby inhibiting protein trafficking through the Golgi. J. Biol. Chem. 2006, 281, 14144-14150. [CrossRef]

47. Pham, T.; Perry, J.L.; Dosey, T.L.; Delcour, A.H.; Hyser, J.M. The Rotavirus NSP4 Viroporin Domain is a Calcium-conducting Ion Channel. Sci Rep. 2017, 7, 43487. [CrossRef]

48. Croft, S.N.; Walker, E.J.; Ghildyal, R. Picornaviruses and Apoptosis: Subversion of Cell Death. mBio 2017, 8. [CrossRef]

49. Okamoto, T.; Suzuki, T.; Kusakabe, S.; Tokunaga, M.; Hirano, J.; Miyata, Y.; Matsuura, Y. Regulation of Apoptosis during Flavivirus Infection. Viruses 2017, 9, 243. [CrossRef]

50. Zhou, X.; Jiang, W.; Liu, Z.; Liu, S.; Liang, X. Virus Infection and Death Receptor-Mediated Apoptosis. Viruses 2017, 9, 316. [CrossRef]

51. Zhang, Y.; Li, Z.; Ge, X.; Guo, X.; Yang, H. Autophagy promotes the replication of encephalomyocarditis virus in host cells. Autophagy 2011, 7, 613-628. [CrossRef] [PubMed]

52. Shi, X.; Chen, Z.; Tang, S.; Wu, F.; Xiong, S.; Dong, C. Coxsackievirus B3 infection induces autophagic flux, and autophagosomes are critical for efficient viral replication. Arch. Virol. 2016, 161, 2197-2205. [CrossRef] [PubMed]

53. Hsu, N.Y.; Ilnytska, O.; Belov, G.; Santiana, M.; Chen, Y.H.; Takvorian, P.M.; Pau, C.; van der Schaar, H.; Kaushik-Basu, N.; Balla, T.; et al. Viral reorganization of the secretory pathway generates distinct organelles for RNA replication. Cell 2010, 141, 799-811. [CrossRef] [PubMed]

54. Suhy, D.A.; Giddings, T.H., Jr.; Kirkegaard, K. Remodeling the endoplasmic reticulum by poliovirus infection and by individual viral proteins: An autophagy-like origin for virus-induced vesicles. J. Virol. 2000, 74, 8953-8965. [CrossRef] [PubMed]

55. Gosert, R.; Egger, D.; Bienz, K. A cytopathic and a cell culture adapted hepatitis A virus strain differ in cell killing but not in intracellular membrane rearrangements. Virology 2000, 266, 157-169. [CrossRef]

56. Teterina, N.L.; Bienz, K.; Egger, D.; Gorbalenya, A.E.; Ehrenfeld, E. Induction of intracellular membrane rearrangements by HAV proteins 2C and 2BC. Virology 1997, 237, 66-77. [CrossRef]

57. Kirkegaard, K. Subversion of the cellular autophagy pathway by viruses. Curr. Top. Microbiol. Immunol. 2009, 335, 323-333.

58. Berryman, S.; Brooks, E.; Burman, A.; Hawes, P.; Roberts, R.; Netherton, C.; Monaghan, P.; Whelband, M.; Cottam, E.; Elazar, Z.; et al. Foot-and-mouth disease virus induces autophagosomes during cell entry via a class III phosphatidylinositol 3-kinase-independent pathway. J. Virol. 2012, 86, 12940-12953. [CrossRef] 
59. Crawford, S.E.; Hyser, J.M.; Utama, B.; Estes, M.K. Autophagy hijacked through viroporin-activated calcium/calmodulin-dependent kinase kinase-beta signaling is required for rotavirus replication. Proc. Natl. Acad. Sci. USA 2012, 109, E3405-E3413. [CrossRef]

60. Yoon, S.Y.; Ha, Y.E.; Choi, J.E.; Ahn, J.; Lee, H.; Kweon, H.S.; Lee, J.Y.; Kim, D.H. Coxsackievirus B4 uses autophagy for replication after calpain activation in rat primary neurons. J. Virol. 2008, 82, 11976-11978. [CrossRef]

61. Boehning, D.; Patterson, R.L.; Sedaghat, L.; Glebova, N.O.; Kurosaki, T.; Snyder, S.H. Cytochrome c binds to inositol $(1,4,5)$ trisphosphate receptors, amplifying calcium-dependent apoptosis. Nat. Cell Biol. 2003, 5, 1051-1061. [CrossRef] [PubMed]

62. Zhou, Y.; Frey, T.K.; Yang, J.J. Viral calciomics: Interplays between $\mathrm{Ca}^{2+}$ and virus. Cell Calcium 2009, 46, 1-17. [CrossRef] [PubMed]

63. Cong, H.L.; Du, N.; Yang, Y.; Song, L.; Zhang, W.L.; Tien, P. Enterovirus 71 2B Induces Cell Apoptosis by Directly Inducing the Conformational Activation of the Proapoptotic Protein Bax. J. Virol. 2016, 90, 9862-9877. [CrossRef] [PubMed]

64. Philpott, D.J.; Sorbara, M.T.; Robertson, S.J.; Croitoru, K.; Girardin, S.E. NOD proteins: Regulators of inflammation in health and disease. Nat. Rev. Immunol. 2014, 14, 9-23. [CrossRef] [PubMed]

65. Rehwinkel, J.; Reise Sousa, C. RIGorous detection: Exposing virus through RNA sensing. Science 2010, 327, 284-286. [CrossRef] [PubMed]

66. Iwasaki, A.; Medzhitov, R. Regulation of adaptive immunity by the innate immune system. Science 2010, 327, 291-295. [CrossRef] [PubMed]

67. Tschopp, J.; Schroder, K. NLRP3 inflammasome activation: The convergence of multiple signalling pathways on ROS production? Nat. Rev. Immunol. 2010, 10, 210-215. [CrossRef]

68. Bauernfeind, F.; Ablasser, A.; Bartok, E.; Kim, S.; Schmid-Burgk, J.; Cavlar, T.; Hornung, V. Inflammasomes: Current understanding and open questions. Cell. Mol. Life Sci. 2011, 68, 765-783. [CrossRef]

69. Triantafilou, K.; Kar, S.; van Kuppeveld, F.J.; Triantafilou, M. Rhinovirus-induced calcium flux triggers NLRP3 and NLRC5 activation in bronchial cells. Am. J. Respir. Cell Mol. Biol. 2013, 49, 923-934. [CrossRef]

70. Wang, Y.; Gao, B.; Xiong, S. Involvement of NLRP3 inflammasome in CVB3-induced viral myocarditis. Am. J. Physiol. Heart Circ. Physiol. 2014, 307, H1438-H1447. [CrossRef]

71. Ichinohe, T.; Pang, I.K.; Iwasaki, A. Influenza virus activates inflammasomes via its intracellular M2 ion channel. Nat. Immunol. 2010, 11, 404-410. [CrossRef] [PubMed]

72. Chen, I.Y.; Ichinohe, T. Response of host inflammasomes to viral infection. Trends Microbiol. 2015, 23, 55-63. [CrossRef] [PubMed]

73. Cornell, C.T.; Kiosses, W.B.; Harkins, S.; Whitton, J.L. Inhibition of protein trafficking by coxsackievirus B3: Multiple viral proteins target a single organelle. J. Virol. 2006, 80, 6637-6647. [CrossRef] [PubMed]

74. Medina, G.N.; Segundo, F.D.; Stenfeldt, C.; Arzt, J.; de Los Santos, T. The Different Tactics of Foot-and-Mouth Disease Virus to Evade Innate Immunity. Front. Microbiol. 2018, 9, 2644. [CrossRef] [PubMed]

75. Zhou, Z.; Mogensen, M.M.; Powell, P.P.; Curry, S.; Wileman, T. Foot-and-mouth disease virus 3C protease induces fragmentation of the Golgi compartment and blocks intra-Golgi transport. J. Virol. 2013, 87, 11721-11729. [CrossRef]

76. Mousnier, A.; Swieboda, D.; Pinto, A.; Guedan, A.; Rogers, A.V.; Walton, R.; Johnston, S.L.; Solari, R. Human rhinovirus 16 causes Golgi apparatus fragmentation without blocking protein secretion. J. Virol. 2014, 88, 11671-11685. [CrossRef] [PubMed]

77. Moffat, K.; Knox, C.; Howell, G.; Clark, S.J.; Yang, H.; Belsham, G.J.; Ryan, M.; Wileman, T. Inhibition of the secretory pathway by foot-and-mouth disease virus $2 \mathrm{BC}$ protein is reproduced by coexpression of $2 \mathrm{~B}$ with 2C, and the site of inhibition is determined by the subcellular location of 2C. J. Virol. 2007, 81, 1129-1139. [CrossRef] [PubMed]

78. Si-Tahar, M.; Blanc, F.; Furio, L.; Chopy, D.; Balloy, V.; Lafon, M.; Chignard, M.; Fiette, L.; Langa, F.; Charneau, P.; et al. Protective role of LGP2 in influenza virus pathogenesis. J. Infect. Dis. 2014, 210, $214-223$. [CrossRef]

79. Zhu, Z.; Li, C.; Du, X.; Wang, G.; Cao, W.; Yang, F.; Feng, H.; Zhang, X.; Shi, Z.; Liu, H.; et al. Foot-and-mouth disease virus infection inhibits LGP2 protein expression to exaggerate inflammatory response and promote viral replication. Cell Death Dis. 2017, 8, e2747. [CrossRef] [PubMed] 
80. Xiao, Y.H.; Dolan, P.T.; Goldstein, E.F.; Li, M.; Farkov, M.; Brodsky, L.; Andino, R. Poliovirus intrahost evolution is required to overcome tissue-specific innate immune responses. Nat. Commun. 2017, 8, 375. [CrossRef]

81. Paulmann, D.; Magulski, T.; Schwarz, R.; Heitmann, L.; Flehmig, B.; Vallbracht, A.; Dotzauer, A. Hepatitis A virus protein $2 \mathrm{~B}$ suppresses beta interferon (IFN) gene transcription by interfering with IFN regulatory factor 3 activation. J. Gen. Virol. 2008, 89, 1593-1604. [CrossRef] [PubMed]

82. Shaghaghi, M.; Soleyman-Jahi, S.; Abolhassani, H.; Yazdani, R.; Azizi, G.; Rezaei, N.; Barbouche, M.R.; McKinlay, M.A.; Aghamohammadi, A. New insights into physiopathology of immunodeficiency-associated vaccine-derived poliovirus infection; systematic review of over 5 decades of data. Vaccine 2018, 36, 1711-1719. [CrossRef] [PubMed]

83. Parker, E.P.; Ramani, S.; Lopman, B.A.; Church, J.A.; Iturriza-Gomara, M.; Prendergast, A.J.; Grassly, N.C. Causes of impaired oral vaccine efficacy in developing countries. Future Microbiol. 2018, 13, 97-118. [CrossRef] [PubMed]

84. Ng, Q.; He, F.; Kwang, J. Recent Progress towards Novel EV71 Anti-Therapeutics and Vaccines. Viruses 2015, 7, 6441-6457. [CrossRef]

85. Moraes, M.P.; Segundo, F.D.; Dias, C.C.; Pena, L.; Grubman, M.J. Increased efficacy of an adenovirus-vectored foot-and-mouth disease capsid subunit vaccine expressing nonstructural protein $2 \mathrm{~B}$ is associated with a specific T cell response. Vaccine 2011, 29, 9431-9440. [CrossRef] [PubMed]

86. Scott, C.; Griffin, S. Viroporins: Structure, function and potential as antiviral targets. J. Gen. Virol. 2015, 96, 2000-2027. [CrossRef]

87. Thomaston, J.L.; Polizzi, N.F.; Konstantinidi, A.; Wang, J.; Kolocouris, A.; DeGrado, W.F. Inhibitors of the M2 Proton Channel Engage and Disrupt Transmembrane Networks of Hydrogen-Bonded Waters. J. Am. Chem. Soc. 2018, 140, 15219-15226. [CrossRef]

88. Foster, T.L.; Verow, M.; Wozniak, A.L.; Bentham, M.J.; Thompson, J.; Atkins, E.; Weinman, S.A.; Fishwick, C.; Foster, R.; Harris, M.; et al. Resistance mutations define specific antiviral effects for inhibitors of the hepatitis C virus p7 ion channel. Hepatology 2011, 54, 79-90. [CrossRef]

89. Govorkova, E.A.; Webster, R.G. Combination chemotherapy for influenza. Viruses 2010, 2, 1510-1529. [CrossRef]

90. Wilkinson, J.; Ewart, G.; Luscombe, C.; McBride, K.; Ratanasuwan, W.; Miller, M.; Murphy, R.L. A Phase $1 \mathrm{~b} / 2 \mathrm{a}$ study of the safety, pharmacokinetics and antiviral activity of BIT225 in patients with HIV-1 infection. J. Antimicrob. Chemother. 2016, 71, 731-738. [CrossRef]

91. Khoury, G.; Ewart, G.; Luscombe, C.; Miller, M.; Wilkinson, J. Antiviral efficacy of the novel compound BIT225 against HIV-1 release from human macrophages. Antimicrob. Agents Chemother. 2010, 54, 835-845. [CrossRef] [PubMed]

92. Behmard, E.; Abdolmaleki, P.; Taghdir, M. Understanding the inhibitory mechanism of BIT225 drug against p7 viroporin using computational study. Biophys. Chem. 2018, 233, 47-54. [CrossRef] [PubMed]

93. Luscombe, C.A.; Huang, Z.; Murray, M.G.; Miller, M.; Wilkinson, J.; Ewart, G.D. A novel Hepatitis C virus p7 ion channel inhibitor, BIT225, inhibits bovine viral diarrhea virus in vitro and shows synergism with recombinant interferon-alpha-2b and nucleoside analogues. Antivir. Res. 2010, 86, 144-153. [CrossRef]

94. Pavlovic, D.; Neville, D.C.; Argaud, O.; Blumberg, B.; Dwek, R.A.; Fischer, W.B.; Zitzmann, N. The hepatitis C virus $\mathrm{p} 7$ protein forms an ion channel that is inhibited by long-alkyl-chain iminosugar derivatives. Proc. Natl. Acad. Sci. USA 2003, 100, 6104-6108. [CrossRef] [PubMed]

95. Kurtz, S.; Luo, G.; Hahnenberger, K.M.; Brooks, C.; Gecha, O.; Ingalls, K.; Numata, K.; Krystal, M. Growth impairment resulting from expression of influenza virus M2 protein in Saccharomyces cerevisiae: Identification of a novel inhibitor of influenza virus. Antimicrob. Agents Chemother. 1995, 39, 2204-2209. [CrossRef]

96. Foster, T.L.; Thompson, G.S.; Kalverda, A.P.; Kankanala, J.; Bentham, M.; Wetherill, L.F.; Thompson, J.; Barker, A.M.; Clarke, D.; Noerenberg, M.; et al. =Structure-guided design affirms inhibitors of hepatitis $\mathrm{C}$ virus $\mathrm{p} 7$ as a viable class of antivirals targeting virion release. Hepatology 2014, 59, 408-422. [CrossRef] [PubMed]

97. Schwarz, S.; Wang, K.; Yu, W.; Sun, B.; Schwarz, W. Emodin inhibits current through SARS-associated coronavirus 3a protein. Antivir. Res. 2011, 90, 64-69. [CrossRef] [PubMed] 
98. Caplen, N.J.; Parrish, S.; Imani, F.; Fire, A.; Morgan, R.A. Specific inhibition of gene expression by small double-stranded RNAs in invertebrate and vertebrate systems. Proc. Natl. Acad. Sci. USA 2001, 98, 9742-9747. [CrossRef]

99. Bobbin, M.L.; Burnett, J.C.; Rossi, J.J. RNA interference approaches for treatment of HIV-1 infection. Genome Med. 2015, 7, 50. [CrossRef]

100. Grimm, D.; Streetz, K.L.; Jopling, C.L.; Storm, T.A.; Pandey, K.; Davis, C.R.; Marion, P.; Salazar, F.; Kay, M.A. Fatality in mice due to oversaturation of cellular microRNA/short hairpin RNA pathways. Nature 2006, 441, 537-541. [CrossRef]

101. Palliser, D.; Chowdhury, D.; Wang, Q.Y.; Lee, S.J.; Bronson, R.T.; Knipe, D.M.; Lieberman, J. An siRNA-based microbicide protects mice from lethal herpes simplex virus 2 infection. Nature 2006, 439, 89-94. [CrossRef] [PubMed]

102. Xie, S.Q.; Wang, K.; Yu, W.J.; Lu, W.; Xu, K.; Wang, J.W.; Ye, B.; Schwarz, W.; Jin, Q.; Sun, B. DIDS blocks a chloride-dependent current that is mediated by the 2B protein of enterovirus 71. Cell Res. 2011, 21, 1271-1275. [CrossRef] [PubMed]

103. Harris, J.R.; Racaniello, V.R. Amino acid changes in proteins $2 \mathrm{~B}$ and 3A mediate rhinovirus type 39 growth in mouse cells. J. Virol. 2005, 79, 5363-5373. [CrossRef] [PubMed]

104. Ong, L.L.; Lin, P.C.; Zhang, X.; Chia, S.M.; Yu, H. Kinectin-dependent assembly of translation elongation factor-1 complex on endoplasmic reticulum regulates protein synthesis. J. Biol. Chem. 2006, 281, 33621-33634. [CrossRef] [PubMed]

105. Zhang, Z.; Pan, L.; Ding, Y.; Lv, J.; Zhou, P.; Fang, Y.; Liu, X.; Zhang, Y.; Wang, Y. eEF1G interaction with foot-and-mouth disease virus nonstructural protein 2B: Identification by yeast two-hybrid system. Microb. Pathog. 2017, 112, 111-116. [CrossRef] [PubMed]

106. Batra, J.; Hultquist, J.F.; Liu, D.; Shtanko, O.; Von Dollen, J.; Satkamp, L.; Jang, G.M.; Luthra, P.; Schwarz, T.M.; Small, G.I.; et al. Protein Interaction Mapping Identifies RBBP6 as a Negative Regulator of Ebola Virus Replication. Cell 2018, 175, 1917-1930.e1913. [CrossRef]

107. Shah, P.S.; Link, N.; Jang, G.M.; Sharp, P.P.; Zhu, T.; Swaney, D.L.; Johnson, J.R.; Von Dollen, J.; Ramage, H.R.; Satkamp, L.; et al. Comparative Flavivirus-Host Protein Interaction Mapping Reveals Mechanisms of Dengue and Zika Virus Pathogenesis. Cell 2018, 175, 1931-1945.e1918. [CrossRef] 